\title{
Gejala Pergeseran Salah Satu Ajaran Dasar Kaum Injili ${ }^{1}$
}

\author{
Sadrak Kurang
}

Beberapa dari panitia reuni ini sebenarnya menginginkan agar di sesi ini kita membahas salah satu dari agenda teologi gereja yang saat ini sedang marak dan controversial yakni teologi dan praktek penyembahan Kristen. Namun karena hal ini masih membutuhkan waktu untuk diteliti maka penulis mengubahkannya kepada salah satu hal yang menurut pengamatan penulis, telah mulai bergeser serius dikalangan umat Nasrani pada umumnya dan kaum injili khususnya, walaupun dapat dikatakan bahwa hal itu memang tidaklah terjadi di semua kalangan injili.

Untuk itulah dalam pertemuan reuni alumni STT Jaffray kali ini kami beranggapan bahwa pokok ajaran yang utama dan dasariah yang dimaksudkan itu sebaiknya dibahas dengan maksud untuk memberikan awasan dan mengingatkan kita bahwa selaku alumni sekolah teologi yang beridentitas injili sebaiknya kita terbuka melihat kembali kepada apa yang banyak kita Kabarkan sekarang ini di tengah umat gembalaan yang Tuhan percayakan kepada kita dalam artian bahwa apakah kita sebagai alumni STTJ telah juga terkontaminasi oleh pokok-pokok pikiran yang berkembang di tengah masyarakat dan itu menjadi berita utama kita?. Apakah kita melayani dalam memimpin umat Tuhan tanpa berita yang jelas sebagai tujuan utama? Dengan memperhatikan perilaku dan hasil perilaku kebanyakan umat Kristen dewasa ini di mana-mana, terlihat dengan jelas bahwasanya apa yang diungkapkan Yesus kepada Nikodemus (Yohanes 3) merupakan sesuatu amanah yang patut diulangi kembali teristimewa kepada yang menamakan diri Kristen.

Selama dua-tiga tahun terakhir dalam rangka menghadiri ibadahibadah minggu pagi di berbagai gereja-gereja lokal di beberapa daerah (Jawa, Sulawesi, Kalimantan, Irian dan terakhir Sumatera) baik itu gereja yang digembalakan alumni STTJ maupun yang non alumni STTJ, penulis menemukan secara umum bahwa apa yang dikerjakan oleh kebanyakan mereka adalah melayani jemaat sesuai jemaat sesuai pergumulan umat, yang dalam hal ini menyangkut pergumulan hidup sehari-hari, yakni

${ }^{1}$ Manakala disampaikan dalam pertemuan reuni raya alumni STTJ, 9 Juli 2001. 
bagaimana menghadapi situasi kekinian yang ada di tanah air dan yang juga dihadapi oleh seluruh bangsa kita. Gereja-gereja yang dihadiri dipilih secara acak dan kegiatan pengamatan tersebut dalam hal ini hanya bersifat fact finding.

Berdasarkan penemuan itu maka beberapa pokoknya dituangkan dalam tulisan ini dalam mana yang menjadi fokus adalah menyoroti adanya gejala pergeseran salah satu ajaran dasar dalam pelayanan para gembala injili yakni dari mengabarkan kabar tentang hidup kekal kepada pelayanan dan pemberitaan sekitar pergumulan hidup sehari-hari. Untuk itu maka pada kesempatan ini dibahas beberapa hal sebagai berikut :

1. Beberapa fakta nyata di jemaat.

2. Mengapa terjadi?

3. Kesimpulan dan penutup.

Jadi untuk itu tujuan tulisan ini adalah agar kita bisa melihat fakta yang jelas di mata kita tentang keadaan dan perilaku jemaat kita yang kemungkinan besar sama dengan fakta yang nyata yang sedang hidup di beberapa anggota jemaat yang penulis temukan di lapangan. Kedua adalah kita bermaksud mengenal apa penyebab utama dari fakta itu lalu dicarikan jalan keluarnya yang tidak menyimpang dari Firman Tuhan. Tulisan ini pada dasarnya diharapkan bermanfaat sebagai masukan bagi para alumni STTJ melihat kembali perilaku dan hasil perilaku jemaatnya agar dengan itu kita dapat kembali mengambil jalan yang sesuai dengan mandat yang diberikan Tuhan bagi setiap kita. Selain itu diharapkan pula bahwa selaku gembala pengajar atau pendidik pada sekolah baik teologi maupun umum, kita dapat menilai sampai sejauh mana kita telah bekerja dengan Tuhan dalam hal Roh Kudus melahirkan kembali orang-orang yang kita gembalakan dan kabari Injil.

\section{Beberapa Fakta :}

1. Pernah sekali tatkala penulis diundang memberi ceramah berhubung saat itu diadakan penammatan pada salah satu sekolah Alkitab di satu daerah. Pada kesempatan itu penulis memulai ceramah dengan bertanya satu pertanyaan yang amat fundamental injili. Pertanyaannya adalah "apakah para pelajar sudah yakin diselamatkan? Jawaban yang serentak dan spontan adalah "ya yakin." Kemudian pertanyaan itu disusul dengan meminta yang yakin penuh agar mengangkat tangannya. Semua juga mengangkat tangan pertanda keyakinan mereka. Namun pada pertanyaan kedua, penulis menanyakan pengalaman nyata mereka waktu diselamatkan, mereka mulai diam dan kasak-kusuk. Bagaimana caranya menerima 
Yesus selaku Tuhan dan Juruselamat dan apakah yang dialami orang yang menerimanya, itulah yang rupanya mereka tidak kenal. Dari sekian banyak yang menamat waktu itu, pada saat ini tidak jelas berapa yang masuk dalam ladang pekerjaan Tuhan.

Di daerah ini gereja injili tidak berkembang dengan baik. Hal itu bukan disebabkan oleh jawaban pelajar tadi, tetapi nampaknya merupakan gambaran bahwa ada gejala gembalagembala memang tidak banyak lagi menekankan karya Kristus di Kayu Salib dan pekerjaan Roh Kudus dalam membaharui. Sebab itu para siswa Sekolah Alkitab yang nota benenya adalah berasal dari gereja, kurang mengerti apa dan bagaimana diselamatkan. Tidak mengherankan kalau di sekolah-sekolah Alkitab/teologi masih juga terdapat mahasiswa yang belum mengenal Tuhan. Dalam beberapa tahun terakhir di STTJ saja, berdasarkan laporan pembimbing mahasiswa, dan berdasarkan hasil pengamatan terhadap kehidupan mahasiswa, ditemukan beberapa dari mahasiswa yang memang belum mengenal Tuhan alias belum diselamatkan. Secara ideal adalah bahwa mereka yang datang untuk belajar di STT adalah mereka yang telah dilahirkan kembali oleh Roh Kudus. Tidak disangkal bahwa banyak yang telah mengalami kelahiran baru itu. Kecenderungan beberapa orang tua ${ }^{2}$ mahasiswa mengirim anaknya ke sekolah Alkitab adalah dengan maksud agar mereka dapat dibimbing untuk hidup secara lebih baik dan rohani. Malah ada di antaranya yang bermaksud agar anak mereka direhabilitasi sekaligus dibina. Tujuan yang semacam ini memang kadang berhasil dicapai, tetapi banyak kali juga gagal. Yang menjadi soalnya adalah mereka yang datang ke sekolah teologi rupanya tidak semuanya sudah menerima Tuhan Yesus selaku Tuhannya dan Juruselamatnya. Itu salah satu kenyataan yang ada di sekolah Alkitab.

2. Dalam satu kesaksian seorang missionary ia mengungkapkan suatu pengalamannya yang agak aneh dan jarang terjadi. Bahwa sekali waktu ia diundang oleh seorang temannya yang adalah anggota gereja dimana ia memberi laporan kinerjanya selama satu periode pelayanan missionary ini di luar negerinya. Pada saat ia tiba di rumah temannya itu, kepala rumah tangga itu memperkenalkan anggota keluarganya kepada tamunya si missionary tadi. Tiba pada giliran memperkenalkan seorang

${ }^{2}$ Di sini menekankan "beberapa", artinya beberapa yang pernah kami temukan. Jadi tidak semua. 


\section{Iutral Teologi STT Jaffray Makassar}

anaknya yang masih remaja, bapak itu menyebutkan namanya dan menyambungnya dengan kalimat, "tetapi ia belum dilahirkan kembali". Pengungkapan hal semacam ini sebenarnya tidak tepat untuk disebutkan kepada tamu atau siapapun teman oleh seorang ayah ataupun ibu. Hanya bahwa dari peristiwa tersebut terungkap adanya suatu kenyataan bahwa walaupun mereka adalah rumah tangga yang Kristen, hal itu tidak menjamin bahwa semua anggota rumah tangga Kristen telah diselamatkan atau dilahirkan kembali.

3. Dengan meletakkan pemikiran tersebut di atas dalam menganalisis situasi yang terjadi di beberapa negara dan daerah kantong Kristen, maka tidak mengherankan bila di dan dari daerah itu sejumlah anggota gereja juga turut serta mengambil bagian dalam peristiwa-peristiwa yang menyedihkan dan mengerikan. Terlepas dari analisis politik ataupun situasi sosial ekonomi atau apa saja namanya, mungkin bisa dinilai bahwa walaupun terdapat banyak gereja di sana perilaku anarkis terjadi pula oleh ulah mereka yang identitasnya Kristen. Jadi nampaknya pengalaman seperti yang ada pada kasus pertama dan kedua di atas dapat dikatakan sedang menggejala luas.

4. Di beberapa jemaat lokal terlihat adanya kekuatiran anggota jemaat atas berbagai situasi yang tengah terjadi di tanah air dewasa ini. Adanya kegiatan kelompok masyarakat yang ingin menegakkan kepentingannya sendiri, munculnya berbagai perbuatan melawan hukum, maraknya penjualan dan pemakaian obat-obat terlarang, penindasan bagi yang lemah, keamanan banyak kali terasa kurang terjamin, harga barang kebutuhan hidup menanjak naik sedang daya beli rakyat secara merata hampir tidak memadai lagi, dll sebagainya. Inilah yang secara umum rupanya mendominasi perhatian para pelayan Firman sehingga dalam khotbah-khotbah minggu pagi umumnya pergumulan itu yang ingin diatasi.

5. Disamping dari itu yang terjadi adalah kehidupan beberapa anggota jemaat secara moral sangat memprihatinkan. Di beberapa daerah yang kebanyakan masyarakatnya beragama Kristen, pola hidup seperti di masyarakat Barat, dalam beberapa hal nampaknya sama. Kalau melirik perilaku masyarakat negeri-negeri yang merupakan sumber agama Kristen di Asia seperti Eropa dan Amerika, di sana terlihat kehidupan yang secara moral bebas dan banyak tidak sejalan peri kehidupan yang diamanatkan Tuhan dalam FirmanNya. Memang di sana tidak terjadi hukum rimba namun tidak dapat dipungkiri bahwa kehidupan seperti misalnya terjadinya perceraian suami istri yang cukup tinggi, sex bebas, perselingkuhan, 
Ketidakjujuran, sikap dan perbuatan tidak menghormati orang tua dan tidak tahu berterima kasih, pornography yang meluas bebas, kebohongan kolektif, ancaman penjahat yang ditandai dengan perlengkapan diri seseorang dengan senjata tajam dan atau senjata api, dan lain-lain perbuatan dan perilaku yang menurut ukuran Firman Tuhan merupakan kejahatan, kini terjadi dalam skala yang nampaknya sudah melampaui batas ambang yang dapat ditolerir. Pertanyaannya adalah mengapa hal semacam ini sangat nampak secara gamblang justru di negeri dan daerah yang masyarakatnya kebanyakan beragama Kristen? ${ }^{3}$

6. Beberapa hasil penelitian yang dituangkan ke dalam tulisan skripsi S1 di STTJ, menunjukkan bahwa di beberapa daerah kini sedang terjadi pola kehidupan rohani Kristen yang tidak menunjukkan kekristenan yang Alkitabiah. Beberapa temuan kasus kehidupan anak-anak muda, yang menjadi sorotan utama penelitian itu, menunjukkan bahwa banyak dari pemuda gereja di daerah yang umumnya masyarakatnya beragama Kristen, jauh dari Tuhan dan hidup tidak sesuai FirmanNya. Sebab itu mahasiswa-mahasiswa itu menyarankan agar pelayanan penggembalaan perlu ditingkatkan demi mengatasi keadaan semacam ini di tiap gereja lokal. ${ }^{4}$

Adalah benar pula bila dikatakan bahwa kenyataan-kenyataan seperti tersebut di atas tidak dapat digeneralisasi, artinya tidak semua orang Kristen itu menghidupi kehidupan yang sedemikian. Namun, kenyataan itu ada dan terjadi sesuai dengan kenyataan yang dikemukakan di atas, dan yang menarik perhatian penulis adalah bahwa kenyataan itu telah makin meluas juga di antara anggota gereja injili. Idealnya adalah bahwa kenyataan seperti itu adalah keadaan dan kehidupan yang tidak boleh terjadi bila kekristenan benar-benar hidup dan dihayati oleh setiap orang Kristen, sebab bila seorang pemeluk Kristen menghidupi kekristenan dengan kata lain melakukan Firman dan bukan hanya

${ }^{3}$ Memang tidak dapat dikatakan bahwa hal semacam ini hanya ada di daerah atau negeri yang didiami kebanyakan oleh kaum Nasrani. Di semua tempat di manapun baik itu didiami umat Kristen maupun yang bukan. Hanya saja memang hal ini memerlukan pengamatan tersendiri lagi sebab tulisan ini hanya dimaksudkan untuk melihat kehidupan kekristenan dalam kaitannya dengan pelayanan para pelayan-pelayan firman.

${ }^{4}$ Skripsi berisi penemuan itu ada beberapa dan dapat ditemukan di perpustakaan STTJ. 
Kenyataan ini bukan pula indikator bahwa para pelayan Firman, gembala jemaat dan pemimpin gereja lainnya, tidak melayani umat gembalaan mereka. Kenyataan pelayanan mereka, bila diamati, ditemukan normal. Mereka melayani pada semua aspek pelayanan pastoral dengan baik dan secara khusus pelayanan firman mereka jalan dengan setia. Jadi bukannya tidak ada pelayanan firman. Itu ada dan terjadi. Hanya mengherankan mengapa bisa terjadi kenyataan di atas sama seperti apa yang banyak terjadi dan meluas dikalangan umat?

\section{Mengapa Terjadi?}

Menyimak fakta di atas kelihatannya ada beberapa hal yang kemungkinan menjadi penyebab utama yang perlu dianalisis, sbb:

\section{Pewarisan Agama:}

Satu fakta sejarah yang terjadi di akhir abad III di saat mana kaisar Roma Konstantinus Agung masuk agama Kristen karena politiknya demikian, hampir semua penduduk kekaisaran itu dikristenkan juga. Khususnya pada saat "Theodosius Agung meneruskan dan menyempurnakan politik Konstantinus. Pada th. 380 ia membuat peraturan bahwa segala penduduk kekaisarannya harus mengikrarkan iman Katolik dari gereja resmi...Pengakuan iman Kristen yang benar (ortodoks) diperintahkan selaku suatu kewajiban terhadap negara dan menganut agama kafir dipandang sebagai suatu pelanggaran politik yang harus dihukum. ${ }^{5}$ Fakta historis ini hampir boleh dikatakan semacam keadaan yang terjadi seperti kenyataan kebanyakan umat Kristen dewasa ini. Mereka memeluk agama Kristen karena kaisar beragama Kristen dan penduduk dipaksa mengikuti agama kaisar itu. Demikian yang ada sekarang bahwa sebab orang tua beragama Kristen anak merekapun harus Kristen. Hal ini wajar, sah dan baik. Namun yang sepatutnya terjadi secara ideal adalah bahwa menjadi Kristen lewat pintu warisan keagamaan akan lebih baik bila didasari atas pemahaman dasar mengapa menjadi Kristen. Jai kekristenan seharusnya dipahami dasarnya oleh anak-anak dalam rumah tangga Kristen. Tanpa memahami pemahaman mereka menjadi Kristen lalu hidup sesuai dengan peraturan agama Kristen menciptakan umat yang panatis, dan

${ }^{5}$ Berkhof, H. dan I. H. Enklaar, Sejarah Gereja, Jakarta: BPK Gunung Mulia 1986, halaman 50. Banding buku sejarah gereja yang ditulis Kenneth Scott LaTourette, A History of Christianity, volume I, hal. 235. 
puas derıan status religiusnya tanpa inemperdulikan perlunya diperbaharui oleh Roh Kudus.

\section{Tantangan Teologi Religionum}

Pada abad 21 dan millennium ke III ini gereja dan masyarakat ditentang oleh suatu keadaan baru yakni keberagaman (pluralist). Di dalam kenyataan baru itu agama-agama diperhadapkan kepada bagaimana mempertahankan identitas masing-masing agama pada suatu sisi dan menghargai agama lain pada sisi yang lainnya. Pengalaman keagamaan pada millennium sebelumnya membuka tantangan itu, sebab dalam masa 2000 th. Di belakang agama-agama saling mempersalahkan dan malah membunuh. Harkat manusia banyak kali diabaikan demi pembelaan suatu ajaran dan agama. Agama dipandang sebagai suatu yang harus dibela mati-matian. Menurut beberapa pandangan bahwa sikap seperti itu dianggap diciptakan oleh adanya ajaran yang diambil dari ayat-ayat yang eksklusif.

Dalam sebuah pertemuan lokakarya dengan rekan-rekan pengajar sekolah teologi, pada suatu saat relak penulis bercakap-cakap dengan beberapa kolega. Dalam percakapan itu seorang rekan memberi suatu pernyataan bahwa sekarang ini kita tidak boleh lagi menekankan pengajaran dari ayat-ayat yang sifatnya eksklusif. Apa yang dimaksudkannya adalah ayat-ayat yang selama ini menjadi ayat pegangan protestan yang menciptakan sifat eksklusif dari pemeluk agama lain. Apa yang ditekankan rekan ini didasari pemikiran teologi religionum. Teologi ini pada dasarnya menekankan sifat universal teologi dan berupa untuk tidak menonjolkan sifat partikularis, apologetis dan polemis teologi yang hal mana menurut pandangan ini malah kalau perlu dibuang. Upaya itu dimaksudkan agar dialog antar pemeluk agama dimungkinkan dan dapat berjalan baik, yang dengan demikian menghindarkan umat beragama di mana saja dari perang umat beragama yang dianggap perang suci, secara khusus antara agama Kristen dan Islam. Dengan itu pula umat beragama dapat saling menghargai dan hidup berdampingan secara harmonis demi membangun masa depan bersama yang aman, damai dan sejahtera. ${ }^{6}$

Pada hakekatnya apa yang dimaksudkan dalam upaya perumusan teologi religionum merupakan sesuatu yang baik saja ditinjau dari sifatnya yang menekankan aspek humanitas keagamaan. Di situ

${ }^{6}$ Teologi Religionum dapat dibaca secara lengkap di buku yang ditulis oleh Tim Balitbang PGI, "Meretas Jalan Agama-Agama di Indonesia", BPK, 1999. 
ditekankan adanya Perdamaian antar sesama manusia dari agama apapun. Hanya saja bahwa dengan berdiri atas pandangan filsafat humanis, peran Tuhan diabaikan dan lalu manusialah yang utama. Upaya ini memang telah populer di antara para tokoh-tokoh muda agama-agama di Indonesia dan telah menyebar luas dikalangan beberapa umat beragama. Bahwa terjadinya perubahan paradigma ini seharusnya tidak membuang paradigma lama yang unik pada kekristenan yakni mengutamakan peran Tuhan. Ayat-ayat eksklusif khususnya menyangkut soteriologi tidak serta merta ditiadakan dengan memberinya interpretasi lain dari yang dimaksudkan oleh Tuhan sebagaimana dimengerti oleh penulis, apalagi kalau dianggap itu bukan yang Tuhan firmankan. Sesungguhnyalah bahwa Tuhan kita Yesus Kristus datang dan menyelamatkan umatnya dari dosa mereka. Roh Kudus menghidupkan, membaharui dan memimpin kita ke dalam semua kebenaran. Tuhan Allah memberi hidup baru, memulihkan hubungan kita kembali dengan-Nya melalui anak-Nya yang Tunggal, Tuhan kita. Kabar baik ini bagaimanapun harus tetap menjadi berita utama dan penekanan yang tidak dapat diabaikan sebab tanpa kabar itu sampai dan diterima serta dihayati maka yang terjadi adalah pengalaman jemaat yang hanya berorientasi humanitas. Hubungan dengan Tuhan terabaikan dan faktor inilah yang menghasilkan umat yang hati dan hidupnya tidak dibaharui sama seperti yang Tuhan anjurkan kepada Nikodemus (Yohanes 3). Berita salib itu bukan dimaksudkan untuk diterima agar dialami sebagai alat/pedang Roh yang membaharui setiap mereka yang menerimanya. Salib adalah tujuan dan jalan yang Allah pilih dalam membuat Ia datang kepada manusia untuk bergaul dan memperkenalkan diri-Nya. Langkah itu pula yang dimaksudkan Tuhan mengutus umat-Nya ke tengah semua orang agar semua orang bisa mengenal Allah. Disinilah bedanya antara Kristen sebagai agama dengan kekristenan sebagai kehidupan pengenalan akan Allah. Kekristenan bukan hasil kristianisasi seperti pada masa kaisar Theodosius Agung tetapi kehidupan yang dibaharui yang hubungan seseorang dengan Allah telah dipulihkan.

\section{Pola Karismatis}

Gerakan kharismatik di penghujung abad XX sampai kini semakin marak baik itu kelompok murni kharismatik maupun yang bukan dari golongan neo-pantekostalisme itu. Pola pemberitaan dan penekanannya adalah pada peran Roh Kudus dan secara khusus, yang kadang berlebihan adalah pada penekanan karunia-karunia rohani. Karunia 
pengadaan mujizat. Karunia penyembuhan penyakit, karunia berbahasa Roh dan kegiatan Pengusiran iblis (exorsisme) adalah kegiatan-kegiatan yang sangat menonjol. Penekanan pada karunia rohani ini dikaitkan dengan sangat tegas dengan apa yang sekarang dikenal dengan sebutan Teologi sukses (prosperity theology). Mereka yang disebut anak-anak Allah diyakini bagaimanapun juga akan sukses. Mereka akan berhasil dalam segala usaha, tidak sakit dan ujungnya adalah kehidupan yang berada. Landasan filsafatnya adalah bahwa Allah adalah Bapa. Kalau Allah itu kaya dan memang Dia kaya, maka anak-anak-Nya pastilah berada juga. Kalau terjadi hal yang berlawanan dengan itu maka seseorang harus dipulihkan sebab penyebab dari kebangkrutan, misalnya, tidak lain adalah dosa. Ia harus bertobat dan dipulihkan. Dan dalam segala sesuatu ia harus tahu bersyukur lebih dahulu dan hidup dikuduskan barulah ia akan memperoleh Kelimpahan hidup itu selaku anak-anak Tuhan. ${ }^{7}$

Untuk hal ini kita tidak sedang dalam menganalisis dan menilai teologi gerakan kharismatik. Yang coba kita soroti di sini adalah mengenai pengaruh adanya penekanan dan ajaran mereka yang menyebabkan sehingga sebahagian dari kita telah mulai lalai dalam memberikan pengajaran ajaran yang sehat dan teguh tentang salib Kristus. Tidak berarti bahwa kelompok kharismatik itu tidak mengajarkan ajaran keselamatan dari Kristus. Berdasarkan fakta, banyak yang "ikut bergabung" ${ }^{\prime}$ kedalam kelompok ini dan aktif dalam pelayanan dan ibadah adalah karena telah mengalami mujizat, atau kesembuhan ataupun karena sudah kembali sukses. Kalau lebih banyak kita menekankan hal lain selain salib Kristus akan mudah tercipta dalam kekristenan yang antroposentris dan bukannya kristosentris. Berita utama dan hidup kita berpusat pada Yesus Kristus Tuhan kita dan bukan pada diri kita. Itu berita yang mengubahkan hati dan hidup setiap orang yang menerimanya sejak jaman dahulu sampai hari ini. Dapat Tuhan Yesus, dapat semuanya, semua dalam Yesus dan Yesus semuanya. Hanya Yesus warta kita, hanya Yesus selamanya Yesus, hanya Yesus kidung kita, Juruselamat, Pengudus, Tabib, Dialah raja termulia.

\section{Kelemahan sumber Daya Manusia}

${ }^{7}$ Lihat buku J. Mac Arthur, Apakah Karismatik itu?,Eklesia, Lawang dan The Charismatic Phenomenon, oleh Masters, Peter and John C. Whitcomb, The Wake man Trust, London, 1989.

${ }^{8}$ Maksudnya ada yang bergabung karena menerima Yesus, ada pula yang karena penyebab yang lain. 
Nampaknya faktor kemampuan sumber daya seorang gembala selaku pemimpin dan pengajar merupakan pula salah satu dari penyebab munculnya kenyataan perilaku hidup yang belum dilahirkan kembali. Dalam hal ini ada dari gembala yang tidak terampil mengajar dan berkhotbah sehingga memang tidak mengherankan adanya anggota jemaat yang tidak hidup sebagaimana layaknya seorang yang disebut Kristen sebab mereka tidak mengerti apa yang diajarkan Tuhan bagi mereka. Ada pula di lapangan terdapat gembala yang amat acuh terhadap keadaan jemaatnya. Umumnya gembala yang seperti ini tidak mempunyai visi atau fokus pelayanan. Sebab itu mereka seakan tidak memperdulikan kalau jemaatnya itu perlu diajari dan dibimbing dengan Firman Tuhan. Umumnya gembala seperti ini hanya santai, atau malah seperti terpaksa walaupun kelihatannya sibuk melayani. Sikap seperti ini juga terdapat di lapangan dan di jemaat yang gembalanya sedemikian terdapat jemaat yang umumnya hidup sama seperti orang duniawi.

\section{Kesimpulan dan Penutup:}

Dari sekian banyak kemungkinan faktor penyebab itu, tidaklah berarti bahwa pada setiap jemaat terdapat semua penyebab itu. Penyebab itu bukan sesuatu yang mutlak bahwa karena hal itu ada maka kelemahan terjadi. Kenyataan kehidupan yang belum dilahirkan kembali itu dapat saja terjadi karena salah satu dari faktor di atas. Yang jelas ialah bahwa yang membuat seseorang dilahirkan kembali itu adalah Roh Kudus. Ia memakai kita selaku hambanya lewat upaya pelayanan kita yang memberitakan Injil Yesus Kristus dan bukan yang lain. Untuk itu maka perlulah kiranya tidak hanya menunggu KKR yang istimewa, yakni yang khusus dilakukan dengan mengundang Pengkhotbahpengkhotbah kawakan dari luar gereja lokal kita. Pada dasarnya KKR itu baik adanya dan dapat dipakai Tuhan. Sebaliknya sebagai seorang gembala kita sendirilah yang berusaha mengajarkan ajaran sehat yang berpusat pada Injil Kerajaan Allah itu. Tuhan memakai kita sebab Ia beserta kita. Ia menginginkan kita memberitakan Yesus, Anak Allah yang Mahatinggi itu. Kabar dan isi pelajaran tentang Yesus itu bukan pengajaran yang sepintas lalu seperti yang banyak dilakukan dewasa ini, yang hal mana pada umumnya itu disebabkan oleh beberapa faktor di atas, melainkan adalah berita dan isi pelajaran yang tetap dan patut berulang. Cerita Tuhan Yesus, kusuka masyurkan, cerita itu indah dan memanglah benar, betapalah indahnya kalau diulangkan, dst. 
Kiranya kabar utama yang adalah ajaran pokok injili itu patutlah disegarkan kembali betapapun kunonya. Banyak strategi dan metode penyampaian untuk itu, tetapi yang utama di sini adalah peran Roh Kudus, pribadi yang ingin anda selaku hambanya mengerjakannya secara nyata di dunia ini sehingga tidaklah terjadi kasus-kasus kehidupan yang belum mengalami kelahiran kembali itu di jemaat anda. Itu diucapkan Yesus dengan berkata "Jikalau Penghibur yang akan Ku utus dari Bapa datang, yaitu Roh kebenaran yang keluar dari Bapa, ia akan bersaksi tentang Aku. Tetapi kamu juga harus bersaksi karena kamu semula bersama-sama dengan Aku." (Yohanes 15:26-27).

Selamat memberitakan Injil Yesus Kristus baik di luar maupun di dalam jemaat yang anda sebagai alumni kerjakan bagi Dia, Tuhan kita Yesus Kristus. Bagi Dialah kemuliaan selama-lamanya. 